damment de la qualité ou du contenu des directives à l'urgence, et de l'amélioration potentielle de la sécurité de la sédation à l'urgence, je doute qu'un Conseils d'anesthésistes ou un comité des normes puisse endosser ces directives et survivre. C'est trop à l'encontre de leur nature.

Les représentants de la SCA qui ont participé au processus et révisé les directives étaient des types sympathiques avec de bonnes intentions. Ils nous ont fait des commentaires utiles et ont probablement contribué à l'amélioration de la qualité de notre produit final. Cependant, il est de mon avis qu'il n'y avait aucune chance que la SCA endosse nos directives de sédation à l'urgence. Des indices de ce dénouement sont apparus tôt dans le processus lorsque les critiques de la SCA ont semblé comprendre tout de travers nos directives préliminaires. C'était comme si celles-ci eussent été tellement déplaisantes qu'il leur était impossible de les évaluer objectivement.
Le refus de la SCA d'endosser les directives de l'ACMU sera vu par certains comme la preuve que les directives sont imparfaites ou dangereuses. Afin de dissiper cette notion, il est important de faire connaître les inquiétudes spécifiques de la SCA ainsi que les réponses fournies par le groupe de travail des urgentologues et ce, avant que celle-ci ne décide de ne pas endosser les directives.

Suite à la page 136 (en Anglais)

\title{
Call for Abstracts 8th International Conference on Emergency Medicine
}

\author{
May 4-7, 2000 \\ Boston, Massachusetts, USA
}

Deadline for submission is November 1, 1999. Decisions mailed by January 15, 2000.

The 8th International Conference on Emergency Medicine (8th ICEM) is now accepting abstracts for oral or poster presentations during the conference. This international conference is hosted by the American College of Emergency Physicians (ACEP). The British Association for Accident and Emergency Medicine will manage its own Call for Abstracts. Please contact BAEM directly for information about their deadlines and submission standards. All other participants should respond to this invitation and send their abstract submissions to Dr. Marsha Ford.

Seventeen educational tracks include: Care Delivery Systems, Administration, International Development, Disaster Medicine, Infectious Diseases, Medical Information Systems, Pediatrics, Trauma, Obstetrics/Gynecology, Toxicology, Medical Imaging, Out-of-Hospital/Emergency Medical Services, Education, International Societal Issues, Environmental Medicine, Internal Medicine, and Anesthesia/Airway/Analgesia.

Abstract submissions to both the 1999 ACEP Research Forum as well as the 2000 Society for Academic Emergency Medicine (SAEM) Conference may also be submitted for consideration to the 8th ICEM without jeopardy.

Information on abstract format, cover sheet and guidelines may be obtained four ways: a) ACEP On FAX at 800-406-2237, document 80159 b) e-mail your request to edmeetings@acep.org, c) visit our website at www.acep.org/8thinter/8thinter.htm, or d) call 800-798-1822, touch 6, or 972-550-0911.

Submit original and eight copies of your abstract to: Marsha Ford, MD, FACEP, 8th ICEM Conference Coordinator, American College of Emergency Physicians, P.O. Box 619911, Dallas, Texas, 75261-9911. Street address for express shipping: 1125 Executive Circle, Irving, Texas, 75038-2522.

Submission in electronic format (Microsoft Word or text file) is required. Abstracts are limited to 200 words. Submit with one inch margins and double spacing on $8 \frac{1}{2} \times 11$ paper. Font should be at least 10 point. Abstracts submitted to the Society for Academic Emergency Medicine (SAEM) may use the their format. Abstracts must include the Abstract cover sheet, found quarterly in the Annals of Emergency Medicine and ACEP's website at www.acep.org.

The Annals of Emergency Medicine, the official journal of the American College of Emergency Physicians, will publish all accepted abstracts in the May 2000 issue. 